\title{
Learning Tools Development of Blended Learning Model on Hydrocarbon Topics to Improve Students Self-Regulation
}

\author{
Norhalisah $^{1 *}$, Suryajaya ${ }^{2}$, Arif Sholahuddin ${ }^{3}$ \\ ${ }^{1}$ Masters Program of Natural Sciences Teaching, Lambung Mangkurat University, Banjarmasin, Indonesia \\ ${ }^{2}$ Department of Physics, Faculty of Mathematics and Natural Science, Lambung Mangkurat University, Indonesia \\ ${ }^{3}$ Department of Chemistry Education, Faculty of Teacher Training and Education, Lambung Mangkurat University, Indonesia
}

DOI: $\underline{10.36348 / \text { jaep.2020.v04i06.005 }}$

| Received: 30.05 .2020 | Accepted: 08.06.2020 | Published: 12.06.2020

*Corresponding author: Norhalisah

\section{Abstract}

This study aims to evaluate the validity, practicality and effectiveness of learning tools using Blended Learning models to improve Self Regulation of student learning on hydrocarbons and petroleum materials. The development model used is the Tessmer Design which consists of stages 1) self evaluation, 2) expert opinions (3), 3) individual test, 4) small group test (small group) evaluation), and 5) Field test. The validation of learning tools, media, and self regulation questionnaires were each carried out by 3 expert validators. Research subjects in the one to one test amounted to 3 students aimed at analyzing the readability of teaching materials and LKPD, research subjects in small class tests totaling 12 people aimed at measuring the practicality and effectiveness of the learning device expectations. Research subjects in the field test totaled 36 students of class X A Multimedia SMK Negeri 3 Banjarmasin aimed at measuring the practicality and actual effectiveness of the learning device prototype. The results showed that the learning tools developed had a very valid category based on expert judgment, were very practical based on the feasibility of learning in class and student responses, and were very effective based on students' mastery learning with an N-gain of 0.36 of the moderate improvement category. Based on the results of research and development shows that the learning device developed is suitable for use in learning hydrocarbon and petroleum materials.

Keywords: Blended learning, self regulation, learning tools.

Copyright @ 2020: This is an open-access article distributed under the terms of the Creative Commons Attribution license which permits unrestricted use, distribution, and reproduction in any medium for non-commercial use (NonCommercial, or CC-BY-NC) provided the original author and sources are credited.

\section{INTRODUCTION}

21st Century learning requires innovation that can deliver students ready to face the future. The concept put forward by Trilling and Fadel [1] 21st Century Skill which includes three things, among others: (1) life and career skills, (2) learning and innovation skills, and (3) information media and technology skills. This is clearly stated in the 2013 curriculum that is preparing students to be skilled in the future. Life and career skills are directed so that students have the ability to adapt to change and are flexible in learning and group work. Have initiative and can manage themselves, have the ability to interact and cooperate effectively, are able to produce products and have the ability to lead and be responsible.

Collaborative skills show an attitude of acceptance towards others, sharing and jointly achieving common goals. The collaborative learning paradigm facilitates students in their respective roles, implementing them, and taking responsibility. Every competency in each learning is collaborated, so that it can improve competence and achievement of results. Mastery of communication information technology is a must for all teachers in all subjects. The mastery of ICT is not limited to knowledge, but the practice of its use. Learning methods that can accommodate this are related to the use of varied learning resources, both conventional and digital learning resources. Students utilize digital sources, both offline and online. Making ICT-based products, both audio and audiovisual.

In connection with this, it is necessary to innovate and change learning activities including the Vocational High School (SMK). Vocational School is a school with a competency-based vocational education system that links and matches with industry, which produces graduates who are ready to work, continue their studies, and are also entrepreneurial. The percentage of SMK graduates to work must range from 80 percent, continuing 10 percent, and entrepreneurship 10 percent. Delivering students as students to become workers certainly requires preparation, in addition to 
knowledge, especially skills are more attitudes that need to be trained, how the work ethic is used as a school culture, so as to produce graduates who are productive, quality and have great skills. According to Tasmara the work ethic is a totality of one's personality and the way to express, look, believe and give meaning that can encourage him to act and achieve optimal charity (high performance).

Chemistry learning activities at SMK 3 Banjarmasin in Mutimedia program, shows learning activities are still centered on the teacher, the subject matter delivered is too abstract, less related to daily life. Opportunities for students to collaborate in solving problems are also very rarely done. The use of the internet is only limited as a source of information even though chemical materials are rich in concepts. Not all concepts can be clearly described, this can be seen from the many students who have difficulty in understanding the subject matter. Nearly $60 \%$ of the chemical value is below the KKM (Minimum Mastery Criteria) which is 70 , especially for material that is conceptual understanding.

Students who do not understand the concept ultimately are passive so that learning activities are only dominated by smart students, students feel afraid when given the task that is done in front of the class, also have a reluctance to ask questions. Students mostly count using the calculators on their mobile phones, or search for answers to questions with the help of Google without understanding the meaning of the answers. Not infrequently home chores that should be used as an exercise to do at home instead done at school.

This raises the assumption that students are not well prepared/self-regulating to participate in learning, both in terms of the preparation of the material to be discussed as well as the preparation of work at home. Another assumption from this reality, could be caused by students being bored with the learning model applied. More broadly speaking, the self regulation of student learning needs to be improved by changing the learning environment and learning styles. According to Zimmerman [2] self-regulated learning occurs when students actively participate in the learning process both in terms of metacognition, motivation, and behavior.

The results of the Chemistry Teacher Subject Discussion (MGMP) Chemistry Vocational School in Banjarmasin also revealed that the majority of the implementation of chemistry learning in schools is still conventional, even though the scope of the chemical material itself is broad, abstract, rich in concepts, contains a lot of formulas, requires time not a few when taught, have links with the environment and everyday life. One of the material that covers these criteria is the material of Hydrocarbons and Petroleum. This results in some important material not being delivered which results in students experiencing learning difficulties, impacting on the development of self-regulation and learning achievement.

Self-regulation is a person's process of determining goals and ways to achieve goals. Determine the target, evaluate, and reward yourself for the goals that have been achieved [3]. One of the selfregulation attitudes that is trained is through the bended learning model. Blended learning comes from English, which consists of two syllables, blended and learning. Blended is a combination or a good combination, and learning is learning. So blended learning is a combination or combination of learning, which is done face-to-face and virtually [4].

Harding, Kaczynski and Wood [5], argued that blended learning is an integration of face-to-face learning and distance learning with online (web-based) learning resources and a variety of communication choices, so learning is more meaningful. The implementation of blended learning allows the use of online learning resources without leaving face-to-face activities, so learning takes place more meaningfully because of the diversity of learning resources obtained. In the learning process, blended learning requires suitable media. One of the media that supports blended learning is moodle application. Moodle is a CMS (Course Management System) that specializes in distance learning (eLearning). In the moodle application you can enter text, graphics, animation, simulation, audio and video.

The significant relationship between self regulated and online learning in the context of blended learning shows that blended learning is an effective strategy in improving students' self regulated learning. Someone who has high self regulated learning will have high learning outcomes [6-10]. Blended learning as a supplement to learning with constructive approaches to the eye Chemistry lessons have several advantages, among others: (1) teaching materials obtained by students are always up to date, (2) mastery of material by students both in face-to-face and online learning can always be controlled by the teacher, (3) learning is more effective and efficient with optimization of the use of information and communication technology (ICT), (4) learning that has not been delivered on faceto-face learning can be completed, (5) effectively improving students' self-regulation in learning activities.

\section{RESEARCH METHODS}

This research is a development research developing learning tools for hydrocarbons and petroleum materials. This research was conducted in two stages, namely the preparation phase and the formative evaluation stage. Formative evaluations include self evaluation, expert review, one to one, small groups, and field tests in Tessmer [11]. The total number of samples was 87 students. The trial design is guided by the 
formative evaluation flow design. Through formative evaluation the validity, practicality and effectiveness of learning tools will be obtained. Data collection techniques are done through observation, documentation, questionnaires, and tests. The instruments used in this study were validation sheets of learning tools (syllabus, lesson plans, modules, worksheets, assessment, learning media), self-regulation student learning questionnaire after blended learning was applied, and observation sheets on teacher and student achievement activities.

\section{RESEARCH RESULTS AND DISCUSSION Learning Tools Validation}

Learning tools that have been prepared based on the results of self-evaluation, validated and reviewed by experts and practitioners. Validated learning tools include syllabus, lesson plans, teaching materials, LKPD, assessment, learning media. Validation is focused on content and is carried out by 3 validators, 2 from academics (lecturers) and 1 practitioner (teacher).

Table-1: Data validation results

\begin{tabular}{|l|l|l|l|l|l|l|}
\hline No & Component & \multicolumn{3}{|l|}{ Score } & Final Score & Category \\
\hline & & V1 & V2 & V3 & & \\
\hline 1 & Syllabus & 4 & 4 & 4 & 4 & Very Valid \\
\hline 2 & Lesspn Plans & 4 & 4 & 4 & 4 & Very Valid \\
\hline 3 & LKPD & 4 & 4 & 4 & 4 & Very Valid \\
\hline 4 & Learning Materials & 4 & 4 & 4 & 4 & Very Valid \\
\hline 5 & Learning Media & 4 & 4 & 4 & 4 & Very Valid \\
\hline
\end{tabular}

Table-1 explains that the syllabus developed obtained a final score of 4 categorized as very valid. In addition to the syllabus, the Learning Implementation Plan that was developed also obtained a final score of 4 categorized as very valid. Overall the Student Worksheet (LKPD) developed to obtain a final score of 4 is considered to be very valid. LKPD is given as a source of learning to direct students to do activities that must be carried out in learning using the Blended Learning model. This worksheet directs students to the stages and processes that students must carry out online or face to face.

Teaching material developed which obtained a final score of 4 was categorized as very valid. Likewise with the learning media obtaining a final score of 4 which is considered very valid. Good learning media will enable students to provide responses, feedback, and also encourage students to practice learning. This is related to the benefits of learning media in the learning process of students, among others, learning will attract more students' attention so that it can foster motivation to learn [12]. The media used in this blended learning model is moodle which validates its content so that a suitable media for the blended learning model is obtained.

The learning device developed by researchers is a learning device model of blended learning to improve student self-regulation of learning. The measured self regulation refers to the standard set by LASSI. Based on the validation of experts, the syllabus developed has met the suitability of the material, learning activities, and assessment. The level of validity of the syllabus that has been reviewed shows a very valid value of 4.0. That means the syllabus developed has met the requirements as a reference for the preparation of the learning framework.
The lesson plan developed by the researcher focuses on the learning steps, especially the core activities, where the core activities reflect the blended learning model in accordance with Grant Ramsay's implementation. The level of validity of the RPP of the results of the study of experts get a final score of 4.0. This shows that the RPP developed is very valid, has been able to describe the substance, facts, concepts, principles contained in the Core Competencies (KI) and Basic Competencies (KD). This is in line with Mulyasa [13] that a good learning implementation plan is a systematic learning process plan and is able to translate $\mathrm{KI}$ and KD into each stage/content of the lesson plan. Improvements to the lesson plan are based on the suggestions given by the validator, so that the lesson plans generated meet the predetermined methods.

Teaching materials and LKPD which are used in research as supporting learning activities are also validated by experts to assess the construction of content/material, language, completeness/presentation techniques, integration and benefits/uses. The level of validity of teaching materials and LKPD results of the study of experts get a final score of 4.0. This shows that the teaching materials and LKPD developed are very valid, already referring to the learning objectives and description of the material, in accordance with Core Competencies (KI) and Basic Competencies (KD), as required for the preparation of good learning resources. UNESCO [14] reinforces the important criteria for good teaching materials is that the material presented is concise and clear, can motivate students, is written in good and correct language and arranged as attractive as possible and accurate.

The learning media used in this blended learning model is moodle whose content is validated so that a media that is able to reflect the blended learning model is obtained. The results of learning media 
validation meet the highly valid criteria of 4.0. This shows that the media developed by researchers has fulfilled the requirements as good media. The right learning media will certainly add to the motivation and ease of students in achieving the learning objectives, this is reinforced by Hamalik's opinion [15] which states that the use of instructional media in the teaching and learning process can arouse new desires and interests, arouse motivation and stimulation, arouse motivation and stimulation of learning activities, and even bring psychological influences on students. The use of instructional media at the learning organization stage will greatly assist the effectiveness of the learning process and delivery of messages or learning systems at the time. Improvements to the media content are based on experts' suggestions including learning videos used on the media must have a separate link so that when the learning process students focus more on observing the video. Also the steps of learning must be clearer, so students easily do learning activities.
The self-regulation instrument used for quantitative analysis of the development of selfregulation of student learning that follows the learning activities of the blended learning model is validated by experts with a final grade of 4.0 and is categorized as very valid. Indicates that the questionnaire that has been prepared can be used as a measurement tool for evaluating the effectiveness of the blended learning model of self-regulation of student learning. Based on the results of the experts' validation of the learning tools and instruments used, it shows that the devices have been categorized as very valid so that the development results can be tested at a later stage, namely the individual test.

\section{Practicality of Learning Tools}

The results of evaluating the feasibility of learning activities are shown in Table-2.

Table-2: The results of observation of activities during learning

\begin{tabular}{|l|l|l|l|l|l|l|l|l|l|}
\hline \multirow{2}{*}{ No } & \multirow{2}{*}{ Learning Activities } & \multicolumn{6}{|c|}{ Average Score for Each Meeting } & Means & Category \\
\cline { 3 - 11 } & & $\mathbf{1}$ & $\mathbf{2}$ & $\mathbf{3}$ & $\mathbf{4}$ & $\mathbf{5}$ & $\mathbf{6}$ & & \\
\hline $\mathbf{1}$ & Opening Activity & 3.5 & 4.0 & 3.5 & 4.0 & 4.0 & 4.0 & 3.83 & Very Practical \\
\hline $\mathbf{2}$ & Main Activity & 3.25 & 3.58 & 3.65 & 3.86 & 3.80 & 4.0 & 3.69 & Very Practical \\
\hline $\mathbf{3}$ & Closing Activity & 4.0 & 3.0 & 3.8 & 4.0 & 4.0 & 4.0 & 3.80 & Very Practical \\
\hline
\end{tabular}

The practicality of the developed learning device refers to the implementation of the learning process in the classroom offline and online learning in accordance with the research design developed in the learning device. Implementation is measured by teacher activities and student activities that are assessed by the observer. The focus of the assessment of the practicality of learning tools is the result of the final stage of development research, namely large group testing or field testing. The implementation of learning activities is seen from the activities of teachers and student activities, teacher activities show an average value of 3.86. This means that learning using development tools has been carried out. Setyowati [16] reinforces that to know the practicality of learning tools can be seen from the ability of teachers to manage learning in class.

Student activities in learning activities show changes, where student activities are increasingly varied. Because in principle learning is an effort to foster student activity so that it must always be created and continue to run using appropriate teaching methods and strategies [17]. In order to make it easier for students to understand and use the moodle application, before learning activities, researchers have made each student's user and password, also conducted socialization on how to use the application until students really understand and are able to use it.

Variative student activities indicate that the self regulation possessed by students begins to develop. At the beginning of learning, many students experienced difficulties and obstacles in carrying out learning activities, this was evidenced by the many questions they raised in the chat media and wa. Indirectly honing and proving the emergence of curiosity about the subject matter delivered also sharpens student self-regulation learning. This is in line with Zimmerman [2] that self-regulation occurs when the active role of students in terms of metacognitive, motivation, and behavior in the learning process increases. Also strengthened by the indicators of independence put forward by Djamarah [18] that students are said to be independent in learning when they already have an awareness of learning goals, awareness of learning responsibilities, and continuity of learning, active learning, and learning efficiency.

The use of blended learning model of learning tools to improve self-regulation of student learning in its implementation requires a high commitment in teaching it, because in addition to learning activities carried out in the classroom, learning is also carried out online outside of face-to-face activities. The ability of mastery of learning media also influences the success of research. Growing awareness and changing student learning patterns is a significant challenge. Students who are accustomed to learning with guidance and direction are invited to find answers themselves to the problems given. Not infrequently the schedule of learning activities that had been agreed upon was delayed only because of classic reasons overslept and also the internet network. So it becomes its own challenges and difficulties for researchers. This has an 
impact on achieving the target and time of completion of the study.

\section{Effectiveness of Learning Tools}

The effectiveness of the learning device is retested by paying attention to cognitive learning outcomes namely from the results of the pretest and posttest assessment. Recapitulation of the pretest and posttest values at the large group test stage can be seen in Table-3.

Table-3: Recapitulation of student's level of understanding

\begin{tabular}{|l|l|l|l|l|l|l|}
\hline Score & Pre-Test & Percentage & Category & Post-Test & Percentage & Category \\
\hline$\geq 70$ & 2 & 5.56 & Complete & 34 & 94.44 & Complete \\
\hline$<70$ & 34 & 9.44 & Not complete & 2 & 5.56 & Not complete \\
\hline
\end{tabular}

Self regulation of student is measured by distributing questionnaires before and after learning activities. The results of self regulation recapitulation can be seen in Table- 4 .

Table-4: Student self-regulation ability

\begin{tabular}{|l|l|l|l|l|l|}
\hline Phase & Total students & Score & Median & N-Gain & Category \\
\hline Initial Phase & 36 & 4077 & 112 & 0.36 & Medium effectiveness \\
\hline Final Phase & 36 & 4658 & 128 & & \\
\hline
\end{tabular}

\section{Learning Outcomes}

A learning tool is said to be effective if it meets the effectiveness criteria, namely the ability of the teacher to manage adequate learning, ideal student activity in the sense of reading, understanding and identifying problem formulation, collecting data, working/completing student worksheets, discussing among fellow students, making conclusions, working on quizzes, the positive response of students to learning activities, where more than $50 \%$ of students gave a positive response to at least $70 \%$ of the number of aspects asked [19].

The effectiveness of the learning tools developed can be seen from the ability of these devices to achieve research objectives or have more value than existing learning devices. In this case, learning tools developed using blended learning models with the aim to improve student self-regulation of learning.

More value from this learning tool is the existence of learning activities that combine direct learning and indirect learning (online), in online learning students learn and find answers themselves to the problems given, while in face-to-face learning, the teacher and students discuss problems that they face during online learning also do exercises contained in LKPD.

The study was conducted at SMKN 3 Banjarmasin in the Multimedia expertise competency program, where the results of the student learning assessment showed 94.44 percent had fulfilled the KKM (Minimum Mastery Criteria) achievement set by the school which was 70 , which meant the learning objectives had been achieved. This is in line with what was stated [20] that learning is said to be effective if what the learning objectives are achieved. The increase in learning outcomes is due to the fact that at the time of the pretest the students had not yet obtained subject matter so that classical completeness was low. Posttest is done after students have obtained subject matter by carrying out learning activities, so that students' knowledge and understanding related to the topic of hydrocarbons and petroleum increase and their learning outcomes also increase. This is in line with the statement of Setyowati [16] that the learning device is said to be feasible if the learning device can support the achievement of learning objectives.

\section{Student Self Regulation}

Self regulation of student learning is measured by using instruments that are distributed before and after learning activities using a blended learning model. Observations were also made on students' learning activities both from the aspect of metacognition, motivation, and behavior. The observations show that overall student learning activities are increasing. This is evidenced by the increase in student learning participation both online and face to face from each learning meeting. This is in line with the statement [21] that the advantages of combination in blended learning can make students more active in the learning process. In the online learning environment, students are required to develop their learning skills from planning learning activities to learning evaluation activities, building more active relationships in cyberspace between teachers and students. This is in accordance with Psaromiligkos \& Retalis [22] that network technology in education has significant potential in promoting interactivity between students and teachers.

Quantitatively the effectiveness of the blended learning model on students' self regulation of learning shows $\mathrm{N}$-gain $=0.36$ which is categorized as moderate effectiveness. This is in line with several studies which concluded that the blended learning model is an effective strategy that can support an increase in selfregulation of learning. Research by Shen et al., [22] added that the combination of blended learning and self 
regulation learning had a higher statistical rate of graduation compared to traditional classes. Tomo and Widada [23] suggested that the use of E-learning website as a learning medium had a significant effect on learning motivation, performance, motivation, readiness, and also had a significant effect on student learning outcomes

However, the current level of effectiveness is one of which is caused when filling in student questionnaires are not guided intensively by researchers so that there are still students filling out questionnaires carelessly. Also a person's self regulation can be more developed because it is influenced by external factors (environment and reinforcement) and internal factors (individual and behavior). Blended learning model of learning activities is very strategic to improve selfregulation of student learning. So it becomes one of the factors that is very supportive in delivering vocational students to become workers who are ready to use. In learning the blended learning model is very demanding of student independence in each stage of learning, training students to select and sort out material and information obtained from the media, making students more free to express opinions without being limited by time and place. Raises self-confidence and discipline and develops appropriate strategies so that the goals are achieved.

The vocational vocational education system is characterized by an apprenticeship/internship program, where each student must carry out these activities for 6 (six) months within a 3-year education period. Students and schools must prepare everything not just knowledge, skills, especially the attitude. The rules that apply in the business/industrial world are very different from those in the school environment. So by practicing self regulation through blended learning, it will greatly support the success of students both in the present and in the future.

\section{CONCLUSION}

Based on research data about the development of learning tools for blended learning models to improve self-regulation of student learning on hydrocarbon and petroleum materials, it can be concluded that:

a. Chemical learning tools (syllabus, lesson plans, LKPD, learning media) models of blended learning topics on hydrocarbons and petroleum to improve self regulation are classified as very valid.

b. Chemistry learning tools (syllabus, lesson plans, LKPD, learning media) model of blended learning topics on hirocarbons and petroleum to improve self-regulation of student learning is classified as very practical based on the implementation of learning by teachers and students.

c. Chemistry learning tools (syllabus, lesson plans, LKPD, learning media) blended learning models of hydrocarbon and petroleum topics to improve self- regulation of student learning are classified effectively based on completeness of student learning outcomes namely $94.44 \%$ of students have reached KKM. The effectiveness of the blended learning model in increasing self regulation of student learning is in the moderate category with $\mathrm{N}$-gain $=0.36$.

\section{REFERENCES}

1. Trilling, B., \& Fadel, C. (2009). $21^{\text {st }}$ Century Skills: Learning for Life in Our Times. San Fransisco: Jossey-Bass.

2. Zimmerman, B. J. (1989). A Social Cognitive View of Self-Regulated Academic Learning: Journal of Educational Psychology. 81(3):329339.

3. Psychologymania.com, https://www.psychologymania.com/2012/04/regul asi-diri-self-regulation.html/27 Mei 2018.

4. Husamah. (2014). Pembelajaran Bauran (Blended Learning). Jakarta. Prestasi Pustaka Jakarta.

5. Rusman, D. K., \& Riyana, C. (2011). Pembelajaran berbasis teknologi informasi dan komunikasi. Bandung: Rajawali Pers.

6. Lynch, R., \& Dembo, M. (2004). The Relationship between Self Regulation and Online Learning in a Blended Learning Context. International Review of Research in Open and Distance Learning, (Online), $5(2): 1-16$, (http://www.irrodl.org/index.php/irrodl/article/vie w/189/799), diakses tanggal 31 Januari 2016.

7. Orhan. (2007). Applying Self Regulated Learning Strategis in a Blended Learning Instruction. World Applied Science Journal, 2(4): 290-398. (Online), (http:// www.idosi.org/wasj/wasj2(4)/ 19.pdf), diakses tanggal 14 Desember 2017.

8. Tsai, C., Shen, P., \& Tsai, M. (2011). Developing An Appropriate Design Of Blended Learning with Web-Enabled Self-Regulated Learning to Enhance Students' Learning and Thoughts Regarding Online Learning. Behaviour \& Information Technology, 30(2):261-271. (http://web.ebscohost.com), diakses tanggal 8 Agustus 2016.

9. Sandi, G. (2012). Pengaruh Blended learning Terhadap Hasil Belajar Kimia DiTinjau dari Kemandirian Siswa. Jurnal Pendidikan dan Pengajaran. 45(3):241-251.

10. Syarif, I. (2012). Pengaruh Model Blended Learning terhadap Motivasi dan Prestasi Belajar Siswa SMK. Jurnal Pendidikan Vokasi. 2(2):234249.

11. Tessmer, M. (1998). Planning and Conducting Formative Evaluations. London: Kogan Page.

12. Sudjana, N. (2010). Belajar dan faktor-faktor yang Mempengaruhinya. Jakarta: Rineka Cipta.

13. Mulyasa. (2013). Pengembangan dan Implementasi Kurikulum. 2013. Bandung: PT.Remaja Rosda Karya. 
Norhalisah et al; J Adv Educ Philos, June, 2020; 4(6): 253-259

14. UNESCO. (1978). Developing Instructional Moduler for Teacher Eduvation-A Handbook. Bangkok: Unesco Regional Office for Educational in Asia and Oceania.

15. Hamalik, O. (1986). Media Pendidikan. Bandung. Alumni.

16. Setyowati, T. (2015). Pengembangan Perangkat Pembelajaran IPA SMP Menggunakan Model Inkuiry Topik Klasifikasi Makhluk Hidup. Magister Pendidikan Biologi. Unlam. Banjarmasin. Tidak dipublikasikan.

17. Rusman, J., Silverbrook, K., \& Lapstun, P. (2010). U.S. Patent No. 7,702,187. Washington, DC: U.S. Patent and Trademark Office.

18. Djamarah., \& Syaiful, B. (2002). Psikologi Belajar. Jakarta. PT. Rineka Cipta.

19. Nurdin. 2007. Model Pembelajaran Matematika yang Menumbuhkan Kemampuan Metakognitif untuk Menguasai Perangkat Pembelajaran. Disertasi. Tidak diterbitkan.Surabaya:Program Pascasarjana Universitas Negeri Surabaya.
20. Plomp, T., \& Nieveen, N. (2007). An Introduction to Educational Design Research. Proceedings of the seminar conducted at the East China University, Shanghai.

21. Kumar, V., Abbas, A. K., \& Aster, J. C. (2017). Robbins basic pathology e-book. Elsevier Health Sciences.

22. Shen, P., Lee, T., \& Tsai, C. 2011. Applying Blended Learning with Web-Mediated SelfRegulated Learning to Enhance Vocational Students' Computing Skills and Attention to Learn. Interactive Learning Environments, (online), 19(2):193209, (http://web.ebscohost.com), diakses tanggal 8 Agustus 2017.

23. Tomo, S., \& Widada, B. (2014). "Pengaruh Pemanfaatan E-Learning terhadap Prestasi Belajar Mahasiswa (Studi Kasus STMIK Sinar Nusantara Surakarta). Jurnal Ilmiah SINUS 12(1), 35-44. STMIK Sinar Nusatara Surakarta". Diakses pada 15 November 2017. 